\title{
İslam Hukukunda Paranın Değer Kaybının Ödenmesini Gerektiren Esaslar $^{1}$
}

Ömer Faruk HABERGETIREN

Yrd. Doç. Dr., Karabük Üniversitesi İlahiyat Fakültesi Asst. Prof. Dr., Karabuk University, Theology Faculty Orcid ID: 0000-0001-9304-6726 ofhabergetiren@hotmail.com

\section{Öz}

İslam bir din olarak sosyal adaleti gerçekleştirmeyi ve refahı toplumun tüm kesimlerine yaymayı amaçlar. İslam hukukunda bu hedefe ulaşmak için bir takım gerekli düzenlemeler yapılmıştır. Maslahat kapsamında yer alan bu düzenlemelerin hedefi tarafların menfaatini koruma ve zarar görmelerini önleme olarak ifade edilebilir. İktisadi hayata ait düzenlemeler de bu kapsamda değerlendirilir.

Ekonomik sıkıntıların yaşandığı, yüksek enflasyon oranının görüldüğü dönemlerde para değer kaybına uğramaktadır. Bunun sonucunda alacaklı konumda olan kimse için bir zararı ortaya çıkmaktadır. İslam hukukun genel prensiplerine göre bu zarar giderilmelidir. Bu da ancak değer kaybının ödenmesiyle mümkündür.

İslam Hukukunda paranın değer kaybının ödenmesi bir takım hukuki esaslara dayanmaktadır. Bu makalede belirlenen bu esaslar belirtilmeye çalışılacaktır.

Anahtar Kelimeler: İslam Hukuku, Para, Borç, Değer kaybı, Zarar.

\section{Principles Pertaining to the Loss of Value of Money in Islamic Law}

\begin{abstract}
Islam, as a religion aims to realize social justice and to spread welfare to all segments of the society. In Islamic law, a number of necessary arrangements have been made to achieve this goal. It may be expressed that these regulations, which fall within the scope of maslaha (general interest) are intended for protecting the interests of the parties and preventing their harm. Regulations of economic life are also evaluated within this scope.

During the periods of economic crises and high inflation money loses its value. As a result, a loss emerges for the creditor. According to the general principles of Islamic law, the creditor must be reimbursed for any financial loss incurred. This is only possible through providing him with the compensation for the loss of monetary value.
\end{abstract}

Islamic Law has established a set of principles concerning the compensation for the loss of monetary value. This paper endeavors to specify these legal regulations.

Keywords: Islamic Law, Money, Debt, Depreciation, Loss.

${ }^{1}$ Bu çalışma “İslam Hukukunda Paranın Değer Kaybı ve Buna Bağlı Hükümler” isimli Yüksek Lisans tezinden aynı başlıklı bölümünün makale formatında geliştirilmesi ile üretilmiştir. 


\section{Giriş}

İslam dininde iktisadi hayat ile ilgili hükümler İslam Hukuku bünyesinde muamelat konuları arasında yer alır. Hukukun temel kaynakları olan Kur'an ve Sünnet, bu konuların temel sınırlarını çizmiş, ayrıntıları ise zaman içinde gelişen toplumsal yapıya bırakmıştır. Toplum farkı gözetilmeden kişiler arasında tüm ticari işlemlerde belirlenen genel prensiplere uyulması istenmiştir. İşlemlerin kuruluşu esnasında bu prensiplere uyulduğu takdirde problemlerin ortaya çıkmayacağı; oluşabilecek sorunların ise kolaylıkla çözülebileceği varsayılmıştır. Hz. Peygamber (sav) döneminden günümüze kadar devam eden tarihi süreç bunun en açı göstergesidir.

İslam'ın hedeflemiş olduğu toplum yapısına ulaşma adına belirlenen kurallar, genellikle maslahat çerçevesinde şekillenir. F1kıh literatüründe maslahat "Ruhî veya bedenî, ferdî veya içtimaî olsun, dünyevî ve uhrevî faydaların sağlanmasını ve zararların giderilmesini belirten bir terim olarak kullanılır fakat maslahatın bu son anlamı daha çok 'def-'i mefsedet' şeklinde ayrı bir prensip olarak incelenir." $2 \mathrm{Bu}$ prensibin altında özellikle fert ve toplum hayatının korunması, istikrarın sağlanması esası yatar. Emir ve yasaklara genel olarak bakıldığında 'bir yararın elde edilmesi ve bir zararın giderilmesi' olgusu/durumu ile karşılaşılır. Toplumsal hayatın ve bu kapsamda iktisadi işlemlerin süreklilik kazanması ve genel bir fayda oluşturması için yarar-zarar dengesine dikkat edilmesi gerekir. $\mathrm{Bu}$ çerçevede ortaya çıkabilecek olumsuzlukların giderilmesi ise daha önemlidir.

İktisadi hayatta çeşitli nedenlerle paranın satın alma gücünde değişiklikler gözlemlenmektedir. Özellikle değer kaybı olarak ortaya çıkan bu durum, ticari işlemlerde birtakım olumsuzluklar meydana getirmektedir. Ticari hayatın canlılığı etkilenmekte, kişiler arasında güven kaybı ve yardımlaşma duygusu zedelenmektedir. Devam eden süreçte toplumun tüm kesimleri bu sorundan zarar görmekte, ekonomik ve sosyal yönden telafisi güç çeşitli problemler ortaya çıkabilmektedir.

Tarihi kaynaklara bakıldığı zaman İslam coğrafyasında altın ve gümüşten imal edilen Dinar ve Dirhemlerin yanı sıra farklı metallerden üretilen Fels (ç. Fulûs) adı verilen para çeşitleri de kullanılmıştır. Zaman içerisinde bu tür paralar, diğer para birimleri karşısında değer kaybına uğramıştır. Böyle bir durumda bazı İslam hukukçuları değer kaybının ödenmesi gerektiğini öngörmektedir. Mal para birimi olarak ifade edilen bu paraların kullanımında görülen sıkıntılar sonrasında günümüzde kâğıt paraların kullanımına geçilmiştir. Tedavülde

\footnotetext{
2 İbrahim Kâfi Dönmez, "Maslahat”, Türkiye Diyanet Vakfi İslam Ansiklopedisi (DİA), İstanbul 2003, c. XXVIII, s. 79.
} 
olan kâğıt paralarda da özellikle enflasyon kaynaklı değer kaybı gözlenmektedir. Oluşabilecek mağduriyeti giderme açısından bu kaybın telafi edilmesi gerektiği belirtilmekte ve bu görüş birtakım hukuki esaslar ve nazariyelere dayandırılmaktadır. ${ }^{3}$

$\mathrm{Bu}$ çalışmanın amacı günümüzde fert ve toplum açısından önemli problemlerden olan paranın değer kaybı ve bu nedenle oluşabilecek zararı tazmin noktasında İslam hukukçularının tespitlerini paylaşmak, alana pratiğe dönüştürülebilecek teoriler hazırlanmasına katkı sunmaktadır.

\section{Akit Günündeki Değer Esası}

Klasik İslam hukuku kaynaklarında altın ve gümüşün "para" işlevini görmek üzere yaratılmış olduğu kaydedilmekte, ${ }^{4}$ bu görevinin dışında başka amaçlar için kullanılması mesela bardak, tabak, çanak, çömlek, kap, kacak gibi mutfak eşyaları yapılmasının haram olduğu belirtilmektedir. ${ }^{5}$ Bu bakış açısına göre eşyanın fiyatını belirlemede asıl olan altın ve gümüştür.

Hanefi müçtehitlerinden İmam Ebû Yusuf'a (v. 182/798) nispet edilen akit günündeki değer esası nazariyesine göre fels'in (ç. fulûs) değer kaybına uğraması (rahs ve kesâd) durumunda akit günündeki değeri esas alınmalıdır. ${ }^{6}$ Buna göre belirlenen değer kaybı dikkate alınarak ödenmelidir. Akit sırasında 100 altın değerinde 1000 fulûsla veresiye olarak yapılan bir bey' akdi sonrasında, ödeme günü gelmeden bu fulûs tedavülden kalksa borcun 100 altın veya değer bakımından buna karşılık gelen yeni para birimleri ile ödemenin yapılması gerekmektedir. Bu görüş, onun fulûs ile yapılan işlemlerde akit günündeki rayiç değeri esas aldığını göstermektedir.

\section{Malların Tazminat Prensibi}

Genellikle ihtiyaçlarımızı gidermek için edindiğimiz, iktisadi bir değer taşıyan, dinen ve hukuken kullanımı mümkün olan maddelere mal denir. İslam hukuku kaynaklarında -birimleri arasında değer farkının bulunup bulunmamasına göre- mal, mislî ve kıyemî olmak üzere iki kısma ayrılır. Fıkıh terimi olarak

\footnotetext{
${ }^{3}$ Bkz. Ali Bakkal, “İslam Hukukunda Para Faiz Telakkisi Zaviyesinden Enflasyon Farkının Ödenmesi Problemi”, Harran Üniversitesi İlahiyat Fakültesi Dergisi, Sayı I, Şanlıurfa, 1995, s. 63 vd. Bu çalışmada adı geçen kaynakta belirlenen esaslar ve nazariyeler temel alınmıştır.

${ }^{4}$ Şemsu'l-Eimme Muhammed b. Ahmed es-Serahsi, el-Mebsut, Beyrut, Dâru'l-Marife, 1414/1993, c. II, s.192; c. XII, s. 115, 137, 183, 200; Şemseddin Muhammed b. Ebi'l-Abbas Şihabuddin erRemlî, Nihâyetu'l-Muhtâc ilâ Şerhi'l-Minhâc, Beyrut, Dâru'l-Fikr, 1404/1984, c. III, s. 84; Vehbe Zuhayli, Fıkhu'l-İslâmî ve Edilletuhu, Dımeşk, Dâru'l-Fikr, tsz. c. III, s. 1328.

${ }^{5}$ Muhammed Emin b. Ömer İbn Abidin, Redd'ul-Muhtâr ale'd-Durri'l-Muhtâr, Beyrut, Dâru'lFikr, 1412/1992, c. VI, s. 341; Ebû Zekeriyya Muhyiddin Yahya b. Şeref en-Nevevî, el-Mecmû Şerhu'l-Muhezzeb, Beyrut, Dâru'l-Fikr, tsz. c. I, s. 256 vd.; Ebû Muhammed Muvaffakuddin Abdullah b. Ahmed İbn Kudâme el-Makdisî, el-Muğnni, Mektebetu'1-Kâhire tsz. c. VII, s. 55 vd.; c. VII, s. 285; c. IX, s. 175.

${ }^{6}$ İbn Abidin, Redd'ul-Muhtâr, IV, 533.
}

Türkiye İlahiyat Araştırmaları Dergisi Turkey Journal of Theological Studies [Tiad: 2602-3067]
Cilt / Vol : 1, Say1/Issue: 1, 2017 
mislî mal, "Fiyatı etkileyecek bir fark olmadan birbirinin yerine geçebilen, görünüm, iç yapı ve ekonomik fayda bakımından eş özelliklere sahip aynı türe ait (standart) mallar"7 olarak tanımlanır. Kıyemî mal ise "Yerini aynı cinsten bir diğeri alamayacak kadar farklı olan ve bundan dolayı da alışverişlerde ferden tayin edilmesi gereken eşya"8 anlamına kullanılır. Kıyemî mallar, misli bulunmayan, bulunsa da insanların takdirine, zaman ve mekâna göre fiyatta aşırı farklılık gösteren mallardır. Mesela hayvan, arazi, ev, mücevherat ve yazma eserler gibi maddeler kıyemî mal olarak kabul edilir. ${ }^{9}$

Felslerin değer kaybı konusunda İmameyn, bu paraları mislî mal gibi değerlendirmiş, tedavülden kalkmaları (kesâd ve ınkıta') halinde, misli bulunmadığı için kıymetlerinin iade edilmesi gerektiğini söylemiştir. Değer kaybetmeleri (rahs) halinde ise İmam Ebu Yusuf'a göre kıymetlerinin iade edilmesi gerekir.10 Günümüzde kullanılan kâğıt paralar da felsler gibi değerlendirip mislî mal olarak kabul edilebilir. Tedavülden kalkmaları veya değer kaybetmeleri durumunda kıymetinin verilmesi alacaklı tarafın zararını giderme açısından daha uygun görülmektedir.

İslam hukukunda mislî mallar, kıyemî mallara dönüşebilir. Hukuk kitaplarında buna örnek olarak birkaç durum belirlenmiştir:11

a) Piyasadan kalkma; mislî mal, tamamen piyasadan çekilmesi ve kullanımdan kalkması durumunda kıyemî mala dönüşür.

b) Karışma; Buğday ve arpa gibi iki ayrı cins kabul edilen iki mislî mal herhangi bir şekilde karıştığı zaman ortaya çıkan bu karışım kıyemî mal değerlendirilir.

c) Tehlikeye maruz kalma; Mislî mal yangın veya sel felaketi gibi bir tehlikeye maruz kaldığı zaman özel bir değer takdir edilerek kıyemî mal sayılir.

d) Kullanılmış ve kusurlu olma; Mislî mal kullanıldığı veya kusurlu bir hale geldiği durumlarda tazmin için özel bir kıymet takdir edilir.

Bir maddenin para olarak kabul edilmesi için, halk tarafından benimsenmesi, devlet otoritesi ve kanun gücü ile desteklenmesi gerekir. Kâğıt paraların tedavülde olmadığı dönemlerde felsler genellikle devrin idarecileri ve valileri

\footnotetext{
${ }^{7}$ Hasan Hacak, “Mislî”, Türkiye Diyanet Vakfı İslam Ansiklopedisi (DIA), İstanbul: 2005, c. XXX, s. 187.

${ }^{8}$ Beşir Gözübenli, “Kıyemî”, Türkiye Diyanet Vakfi İslam Ansiklopedisi (DİA), İstanbul: 2002, c. XXV, s. 540.

${ }^{9}$ Mecelle, 145, 146. mad.

${ }^{10}$ Muhammed Emin b. Ömer İbn Abidin, Tenbih'ur-Rukûd ala Mesâili'n-Nukûd, Mecmuatu'r-

Resail, Mektebetu'l-İslamiyye, tsz. c. II, s. 59.

${ }^{11}$ Zuhayli, Fıkhu'l-İslâmî ve Edilletuhu, IV, 2886.
} 
tarafından basılır, bozuk para ihtiyacını gidermek amacıyla kullanılırdı. İdarecinin değişmesi veya ölümünden sonra bu paralar değerini (itibarını) kaybeder zamanla piyasadan çekilirdi. İslam hukukçularının çoğunluğuna göre bu durumda misil, kıymete dönüşür.

Günümüzde kullanılmakta olan kâğıt paralar da fulûs'la benzer özellikler taşımaktadır. Kıymetlerini devletin gücü ve otoritesinden almaktadır. Yüksek enflasyon oranlarının görüldüğü dönemlerde kâğıt paraların değeri her geçen gün düşmektedir. Bu durum, paraların gerçek değeri ile üzerlerinde yazılı rakam arasında bir irtibatın olmadığını gösterir. Birkaç yıl önce 10 liraya alınan bir madde, bugün yaklaşık 20 liradır. Bu maddeye kıyasla birkaç yıl önceki 10 lira, bu günkü 20 liraya eşittir denilebilir.

Böyle bir değer kaybının görüldüğü durumda birkaç yıl önceki para ile, bu günkü aynı rakam yazılı para değer bakımından eşit değildir, yani bir yıl önceki paranın misli değildir denilebilir. Artık o günkü değer (misil) kaybolduğu ve kusurlu olduğu için para kıymete intikal etmiştir. Ortaya çıkan zararı gidermek amacıyla kıymetinin, yani değer kaybının ödenmesi maslahata uygun bir davranış olacaktır.

\section{Ayıp ve Kusur Nazariyesi:}

İslam hukuku, ortaya çıkabilecek problemleri oluşmadan önlemek amacıyla akitlerin ayıp ve kusurlardan salim olması konusuna önem vermektedir. Hatta Mecellenin birçok maddesi ayıp ve kusur muhayyerliğiyle ilgilidir. ${ }^{12} \mathrm{Bu}$ muhayyerliğin sebebi, malda veya bedelinde kıymeti düşürecek veya arzu edileni elde etmeye mâni olacak ve akit sırasında hiyar/tercih sahibinin bilmediği bir ayıbın (kusurun) ortaya çıkmasıdır. ${ }^{13}$ Ayıp muhayyerliğinin sonucu ise tercih hakkı olan taraf açısından akdi gayr-i lazım yapması, ${ }^{14}$ yani akdi bozma ve ret imkânı vermesidir.

Klasik İslam hukuku kitaplarında semendeki ayıp ve kusur üzerinde yeterince durulmamıştır. İslam tarihinde semen olarak kullanılan maddeler genellikle altın ve gümüşten üretildiği ve bunlarda kısa zaman sürecinde değer kaybı görülmediği için bu konuya temas etme ihtiyacı duyulmamış olabilir. Bununla beraber, kaynaklarda bu hususta çok önemli bazı kayıtlara rastlamak mümkündür. ${ }^{15}$

\footnotetext{
12 Bkz. Mecelle, 336-355, 513-516, 741-742, 787, 814 ve 912. mad.

13 Zuhayli, Fıkhu'l-İslâmî ve Edilletuhu, IV, 3116.

${ }^{14}$ Alâüddîn Ebû Bekr b. Mes'ûd el-Kâsânî, Bedâiu's-Sanâi' fî Tertîbi'Şerâi', Dârü'1-Kütübü'1-

İlmiyye 1406/1986, c. V, s. 27r.

${ }^{15}$ Bkz. Bakkal, "İslam Hukukunda Para Faiz Telakkisi Zaviyesinden Enflasyon Farkının

Ödenmesi Problemi", 66.
}

Türkiye İlahiyat Araştırmaları Dergisi Turkey Journal of Theological Studies

[Tiad: 2602-3067]
Cilt / Vol : 1, Sayı/Issue: 1, 2017 
Mecelle maddeleri arasında akitlerde semenin vasfı ve taraflarca malum oluşu üzerinde özellikle durulmuştur. ${ }^{16}$ Hatta altından üretilmiş farklı türde para (dinar) tedavül eden bir piyasada akit sırasında bedelin mutlak olarak belirtilmesi fesad sebebi sayılmıştır. Bu para, değerini üretildiği maddesinden almaktadır. Fakat revacına göre değer farklılıkları ortaya çıkabilmektedir. Bu sebeple akit esnasında adet olarak miktarı belli olmakla beraber ayrıca cinsinin zikredilmemesi fesad sebebi sayılmıştır.

"Yüksek enflasyon oranlarının görüldügü dönemlerde bazen para o kadar değer kaybetmektedir ki, bunun altından üretilen paraların değer farklılığı ile ölçmek mümkün değildir. Eğer maddesi aynı olan iki altın para revaç düzeyinden kaynaklanan bir farklılık sebebi ile birbirinin yerine kaim olamıyorsa yüksek oranda değer kaybının görüldüğü bir ülkede birkaç yıl önceki kâğıt para, birbirinin yerine nasıl kaim olabilir? Böyle bir durumda para nasıl olur da ayıplı sayılmaz ve değer farkının ödenmesi gerekmez? Ayıp ve kusur nazariyesi gereğince böyle bir şey düşünmek mümkün görünmemektedir."17

Şafii mezhebinde mebi'de olduğu gibi semende de ayıp muhayyerliği söz konusudur. Ayıp taraflara öncelikle akdi bozma hakkını verir. ${ }^{18}$ Akdin bozulması zarara uğrayan tarafı zarardan kurtarmadığı durumlarda, ayıp miktarı kadar bir değer farkının/kaybının ödenmesi gerekir. Buna göre semende, değer kaybı sebebiyle bir ayıp meydana gelmiştir. Akdin fesh edilmesi zarara uğrayan tarafı zarardan kurtarmadığı için ayıp miktarı kadar bir enflasyon farkının ödenmesi gerekir. Karz akdinde de durum bu şekilde değerlendirilebilir. ${ }^{19}$

\section{Aldatmanın Olmaması Esası}

İslam hukukunda aldatmanın (tagrîr) aşırı olması (gabn-1 fâhiş) aldanan kimse için akdi fesh sebebi olarak kabul edilir. ${ }^{20}$ Enflasyonun yüksek seyrettiği dönemlerde borcun bilerek geciktirilmesi bir nevi aldatmadır. Bazen bir aylık geciktirme dahi yüksek bir değer kaybına sebep olabilir.

Günümüze kıyasla çok az oranda enflasyonun görüldüğü dönemlerde belirlenen ölçülere göre aşırı aldanma metada $\% 5$, hayvanlarda $\% 10$, gayr-i

\footnotetext{
16 Bkz. Mecelle, 238-240. mad.

${ }^{17}$ Bakkal, “İslam Hukukunda Para Faiz Telakkisi Zaviyesinden Enflasyon Farkının Ödenmesi Problemi", 66.

18 Şemseddin Muhammed b. Ahmed er-Remlî, Nihâyetu'l-Muhtâc ilâ Şerhi'l-Minhâc, Beyrut, Dâru'l-Fikr, 1404/1984, c. IV, s. 35.

${ }^{19}$ Bakkal, "İslam Hukukunda Para Faiz Telakkisi Zaviyesinden Enflasyon Farkının Ödenmesi Problemi", 67.

${ }^{20}$ Mecelle, 357. mad.
} 
menkulde \%20 ve daha fazlasıdır. ${ }^{21}$ Zamanımızda görülen değer kaybı ise Mecellede verilen bu aldanma ölçülerinden çok daha büyük bir gabn-1 fâhiş olayını beraberinde getirebilmektedir. Yıllık enflasyonun yüksek oranlarda gerçekleştiği dönemlerde "böyle geniş çaplı ve umumi bir aldatmanın önüne geçmek şer'i maslahatın bir icabı ve aldatmanın olmaması nazariyesinin gerektirdiği bir durumdur." 22 Bu nazariyeye göre borcunu bilerek geciktiren, karşı tarafa zarar veren bir kimseden ayrıca değer kaybını da istemek, İslam hukuk prensiplerine uygun bir hüküm olarak kabul edilebilir.

\section{Zararın İzalesi Prensibi}

İslâm'ın zarar vermeyi ve zarara zararla karşılıkta bulunmayı yasakladığı bilinen bir husustur. ${ }^{23}$ Hukuki bir kural olarak zarar verilmemesi, ortaya bir zarar çıktığ 1 durumlarda bunun giderilmesi gerektiği Mecelle maddeleri24 arasında yer almaktadır. Normal şartlar altında dahi borcun geciktirilmesi durumunda alacaklı kişi için bir zarar durumunun ortaya çıkması söz konusu olabilir. Bu tür bir davranışı Hz. Peygamber (sav) de bir "zulüm" olarak nitelemiştir. ${ }^{25}$ Paranın değer kaybı alacaklı durumunda olan kimseler açısından bir zarardır. Buna göre kişilerin değer kaybı sonucunda uğradıkları zararın telafi edilmesini istemek İslâm hukukunda belirlenen genel kaidelere uygun bir hüküm olarak değerlendirilir.

\section{Batıl Yolu Kapama Esası}

Allah (cc) Kur'an-1 Kerim'de "Aranızda birbirinizin mallarım batıl yollarla (haksiz yere) yemeyin" 26 buyurmaktadır. Ayette yer alan "batıl yol" nitelemesinin genel olarak İslam'a göre yasaklanan (gayr-i meşru) her türlü haksız yol ve davranışı içerdiği söylenebilir.

Yüksek enflasyon, ekonomik istikrar için gerekli ve devamı arzulanan bir durum değildir. İktisadi hayatın gidişatını ciddi şekilde etkiler. Tüm idareciler, fiyat artışlarını kontrol altına alma ve durdurma yollarını ararlar. Enflasyon sebebi ile birtakım insanlar haksız bir şekilde zenginleşmekte ve diğer insanların mallarına adeta batıl yolla el koymaktadırlar. Bu yönüyle enflasyon, ekonomik hayat için "batıl yol" olarak nitelendirilebilir. Enflasyon oranının yüksek seyrettiği dönemlerde oluşan bir para borcunu, üzerinde yazılı aynı rakam ile iade edilmesini istemek, hak sahibinin hakkını gasp etmek olarak değerlendirilebilir. Böyle bir yol, hukuken doğru ve dengeli bir davranış da

${ }^{21}$ Bkz. Mecelle, 165. mad.

22 Bkz. Bakkal, “İslam Hukukunda Para Faiz Telakkisi Zaviyesinden Enflasyon Farkının

Ödenmesi Problemi", 68-69.

23 İbn Mâce, Ahkâm 17.

${ }^{24}$ Bkz. Mecelle, 19, 20. mad.

${ }^{25}$ Buhari, İstikraz 12; Müslim, Musâkât 7; ebû Davud, Buyu 10; İbn Mâce, Sadakât 8; Tirmizî, Buyu 68; Nesâî, Buyu 101.

${ }^{26}$ Bakara, 2/188.

Türkiye İlahiyat Araştırmaları Dergisi

Turkey Journal of Theological Studies

[Tiad: 2602-3067]
Cilt / Vol : 1,

Say1/Issue: 1, 2017 
değildir. Batıl yolla insanların parasını haksız olarak yemek, İslâm'da müsaade edilmeyen bir davranıştır.

Kâğıt paralar asli değerini üzerlerinde yazılı olan rakamdan değil o günkü satın alma gücünden almaktadır. Bu bakımdan paranın gerçek değerini ölçmek için, yalnızca üzerinde yazılı olan rakama bakmak doğru değildir. Böyle bir davranış ekonomik açıdan da uygun bir yöntem olarak görülemez. Üzerinde yazılı rakama bakarak, yüksek enflasyon görülen bir ortamda, zimmette borç olarak sabit olan parayı aynen iade etmek, haksız bir para gaspıdır. İslam her türlü batıl yollun karşısındadır; kaynağı hukuka uygun olmayan haksız kazancı ve kul hakkı yemeyi yasaklamıştır. Enflasyon dönemlerinde paranın değer kaybı sonucu ortaya çıkan fark, borçlu olan kimsenin zimmetinde haksız bir kazancın geçmesi sonucunu doğurabilir. Enflasyon sebebi ile ortaya çıkan değer farkının ödenmesinin faiz olmadığı, borcun aslının ödenmesi olduğu belirtilmektedir. ${ }^{27}$ Bu şekilde borç verenin hakkı tam olarak ödenmektedir.

\section{Sermayenin Tabana Yayılması Esası}

Kur'an-1 Kerim'de zekâtın farz oluş hikmeti anlatılırken “...O mallar, içinizden yalnız zenginler arasında dolaşan bir servet (ve güç) haline gelmesin diye (Allah böyle hükmetmiştir)" 28 denilmekte ve zekâtın verilmesinin önemi belirtilmektedir. İslam iktisat düşüncesinde paranın belli bir kesimin elinde büyük miktarda toplanmaması ve refahın tabana yayılması hedeflenir. Para, belli kesimlerin ellerinde toplumsal dengeyi bozacak ve yıkıcı bir güç olacak şekilde büyük miktarda toplanırsa o zaman, bir zulüm ve haksızlık aracı konumuna gelebilir. İslam hukukunda gerek zorunlu gerekse tercihe bağlı olarak yapılması istenilen düzenlemelerle, servetin sadece zengin sınıfın elinde toplanıp toplumsal hayata hâkim konuma gelmesi engellenmek istenir.

Enflasyon insanlar arasında gelir dengesini bozan, maddi farklılı̆̆1 arttıran, adeta zengini daha zengin, fakiri de daha fakir yapan iktisadi bir krizdir. Eğer insanlar bir akit sonrası karşı tarafın zimmetinde borç olarak bıraktıkları paralarını değer kaybını hesap etmeden geri alırlarsa, karşı tarafta enflasyon farkı kadar bir değer artışı (gelir transferi) sağlamış olurlar. Bu durumdan istifade etmek isteyen bazı fırsatçlar da haksız bir zenginleşme içerisine girerek, parayı gereksiz yere ellerinde tutar ve ödemeyi geciktirirler. İslam, böyle bir ortamın oluşmasını gelmesini istemez. Bu durumda alacaklı tarafa

\footnotetext{
${ }^{27}$ Bakkal, “İslam Hukukunda Para Faiz Telakkisi Zaviyesinden Enflasyon Farkının Ödenmesi Problemi", 70 .

${ }^{28}$ Haşr, 59/7.
} 
enflasyon farkının ödenmesi gerektiğini söylemek İslam iktisat hedeflerine uygun ve hiç kimsenin zararına olmayan bir hüküm olacaktır. ${ }^{29}$

\section{Adalet Esas1}

Yüksek enflasyon görülen dönemlerde çalışanların reel gelirleri (maaş ve ücretleri) enflasyon oranında düşmektedir. Böylesi dönemlerde idareciler tarafından ücretlilerin reel kaybını önlemek amacıyla, her yıl sonunda ücretler yeniden değerlendirilerek enflasyon oranında bir zam yapılır. Yönetimde adalet ilkesi bunu gerektirir. İslâm'a göre de durumun böyle olması lazımdır. İslam adalet dinidir, Allah (cc) adildir, adaleti emreder, zulmü yasaklar; ücretlinin hak ettiği ücretin zamanında ve tam olarak ödenmesini ister.

Enflasyonun zararlı etkilerinin görüldüğü dönemlerinde ücretliler devlet eliyle bu şekilde korunurken, ticari işlemlerde ve borç akitlerinde para değeri nasıl korunacaktır. Faizi tüm ticari hayata yaymak İslâm'da kabul edilmeyen bir davranıştır. Bu sebeple borç ve alacaklar hangi nedenden kaynaklanmışsa kaynaklansın enflasyon farkı alınması adalet ilkesine uygun bir hüküm olarak kabul edilmektedir. ${ }^{30}$ Böylece borç veren kimseye bir haksızlık ve adaletsizlik yapılmamakta, borç alan kimsenin de zimmetine haksız bir kazanç geçirilmiş olmamaktadir.

\section{Faiz Nazariyesi}

Faiz lügatte, nema/fazlalık, artış anlamına gelir. Terim olarak "Malların değişiminde, bedelsiz (karşılıksız) olan mal fazlalığıdır." Bu, hakiki olabileceği gibi, vade (içindeki menfaat) gibi hükmi bir fazlalık da olabilir. Ama her iki durumda da karşılığ bulunmayan bir fazlalıktır. ${ }^{31}$

İslam hukukçuları, dönemlerindeki felsler ile altın ve gümüşten üretilen hakiki paraları aynı çerçevede değerlendirmemişlerdir. Felsler, itibari bir para olarak kabul edilmiştir. Bu itibar kaybolunca paranın değeri de yok olur. Hatta Şafiîlere göre felslerde faiz cereyan etmez. ${ }^{32}$

Günümüzde kullanılan kâğıt paralar da bir çeşit itibari kıymete sahiptir. Paranın üzerinde yazan rakama itibar edilmemesi gerekir. Bugün üzerinde 10 TL yazan bir kâğıt para, \%80 enflasyon oranının görüldüğü ortamında bir yıl sonra 18 TL kıymeti ifade eder. Ancak altın böyle değildir. 100 gram altın bir yıl sonra yine 100 gram altındır, değerinde pek fazla bir değişiklik olmaz. Bu nedenle kâğıt para ile yapılan işlemlerde verilecek farkın karşılıksız bir fazlalık

\footnotetext{
${ }^{29}$ Bakkal, “İslam Hukukunda Para Faiz Telakkisi Zaviyesinden Enflasyon Farkının Ödenmesi Problemi", 70.

${ }^{30}$ Bakkal, “İslam Hukukunda Para Faiz Telakkisi Zaviyesinden Enflasyon Farkının Ödenmesi Problemi", 70.

${ }^{31}$ Zuhayli, Fıkhu'l-İslâmî ve Edilletuhu, V, 3698.

32 Zuhayli, V, Fıkhu'l-İslâmî ve Edilletuhu, 3718.
}

Türkiye İlahiyat Araştırmaları Dergisi Turkey Journal of Theological Studies [Tiad: 2602-3067]
Cilt / Vol : 1, Say1/Issue: 1, 2017 
olmadığı, borç verme günündeki değerin aynen ödenmesi olduğu söylenilebilir.

Bir başka açıdan İslâm hukukunda para, mal olarak kabul edilmektedir. Mal, insanların itibar ettiği ve ihtiyaç için sakladığı nesnedir. ${ }^{33}$ Her malın insan nazarında farklı bir itibarı vardır. Bununla beraber itibar, ya altın ve gümüş gibi zatından kaynaklanır veya fulûs gibi zatından kaynaklanmaz. Bir malda hangi itibar ağır basıyorsa hükmün ona göre verilmesi gerekir. ${ }^{34}$ "İtibar galib-i şâyiadır. Nadire değildir." 35 Eğer bir mal değerini, ona olan meyilden ve itibardan alıyorsa o malın değeri zatidir. Bir mal da değerini, zatından değil toplumun onu mal olarak kabulünden alıyorsa onun değeri de itibaridir. Bugünkü kâğıt paraların değeri itibari olduğu için, ödenme durumunda "itibari değer eşitliğine" dikkat edilmesi gereklidir. Eğer bu eşitlik bulunmaz da arada bir değer fazlalığı görülürse bu fazlalık faiz olarak telakki edilebilir. ${ }^{36}$

\section{Değer Kaybının Ödenmesinde Dikkat Edilmesi Gereken Hususlar}

Değer kaybının ödenmesi ve oluşabilecek mağduriyetin giderilmesinde dikkat edilmesi gereken bazı önemli husular da bulunmaktadır. Bunlar şu şekilde özetlenebilir:

Değer kaybı alacaklı taraf açısından genel olarak (örfen) kabul edilebilir bir oranın üstünde gerçekleşmeli ve hak sahibinde bir zarar meydana getirmiş olmalıdır. Alacaklı kimsenin kabul edebileceği ve beklentileri dahilindeki bir kayba akit esnasında rızası bulunduğu varsayılır, bu kayıp daha sonra talep edilemez.

Borç, bir satım akdinden doğmuşsa; belirlenen vade alacaklıya zarar verecek bir süre aşılmış olmalı ve değer kaybı da vade farkı olarak fiyata yansıtılmış olmamalıdır. Karz akdinden kaynaklanmış ise akit öncesi ödemeye ek olarak belli bir miktar veya vadeye karşılık ilave bir oran belirlenmemelidir. Tüm bu belirlemeler hukuken riba/faiz olarak değerlendirilir. Borç para verme işlemleri (karz) genellikle yardımlaşma amacıyla yapılmaktadır. Tüm borçlanmalarda vadenin sebepsiz yere geciktirilmemesi gerekir. ${ }^{37}$ Gecikme durumlarında, kasit ve ihmal unsuru aranmall, iflas, paranın temin edilememesi veya ulaştırılamaması gibi elde olmayan yahut borçlunun zor duruma düşmesi gibi

\footnotetext{
${ }^{33}$ Mecelle, 126. mad.

${ }^{34}$ Bakkal, “İslam Hukukunda Para Faiz Telakkisi Zaviyesinden Enflasyon Farkının Ödenmesi Problemi", 73.

${ }^{35}$ Mecelle, 126. mad.

${ }^{36}$ Bakkal, "İslam Hukukunda Para Faiz Telakkisi Zaviyesinden Enflasyon Farkının Ödenmesi Problemi", 73.

${ }^{37}$ Buhârî, İstikrâz 12.
} 
öngörülmeyen nedenlerde değer kaybı talep edilerek ödeyecek kişi/borçlu daha fazla mağdur edilmemelidir.

Zimmette sabit olan para borcunun, değer kaybı eklenmiş haliyle yeni bir bedelle ödenmesi durumunda ödemenin derhal yapılması gerekir. Yoksa hukuki tabirle "deyn'i deyn ile satma" durumu ortaya çıkacağından bu fazlalık faiz olarak kabul edilir.

Enflasyon ve değer kaybı, piyasanın tabii seyri içinde, normal şartlarda oluşmalı, spekülatif veya devlet kaynaklı ve servet sahiplerine özel (vergilendirme amaçlı) bir uygulama olmamalıdır. Bu durum, sadece servet sahiplerinden alınan bir vergi niteliğinde olduğu için alacak sahibinin bu kaybı kendisinin karşılaması gerekir. Bu yükü karşı tarafın üstlenmesini istemek hukuken ve ahlaken uygun bir davranış olmayacaktır.

\section{Sonuç}

Batılılaşma ve kapitalist düşüncenin hâkim olduğu, değişik yöntemlerle aşırı tüketimin desteklendiği günümüzde çeşitli nedenlerden kaynaklanan iktisadi krizler görülmektedir. Krizlerin iktisadi hayata yansıması birbirinden farklı şekillerde olmaktadır. Bunlar arasında yüksek enflasyon ve paranın değer kaybı da bulunmaktadır. Bu dönemlerde genellikle alacaklı konumunda olan kimseler açısından bir zarar durumu ortaya çıkmaktadır.

İslam Hukuku genel kurallarına göre maslahat çerçevesinde alacaklının menfaatinin korunması ve ona gelen zararın giderilmesi gerekir. Paranın değer kaybı borcun sahibi olan olan taraf açısından bir zarar meydana getirdiğine göre bunun telafi edilmesi hukuki prensiplere uygun bir hüküm olacaktır.

Değer kaybının ödenmesini istemek İslam'ın sosyal adaleti gerçekleştirme ve refahı toplumun tüm kesimlerine yayma hedefine uygun bir davranış olarak değerlendirilebilir ve insani ilişkilerin iyileştirilmesi noktasında önemli katkılar da sunabilir. Ayrıca Kur'an ve Sünnette emredilen yardımlaşma düşüncesinin zarar görmemesi ve sağlıklı bir şekilde devam etmesini sağlayabilir.

İslam hukuku prensiplerine uygun olarak değer kaybının ödenmesini gerekli kılan esaslar şu şekilde belirlenmiştir:

a) Akit günündeki değer esası

b) Malların tazminat prensibi

c) Ayıp ve kusur nazariyesi

d) Aldatmanın olmaması esası

e) Zararın izalesi prensibi

f) Batıl yolu kapama esası

g) Sermayenin tabana yayılması esası

h) Adalet esas1

i) Faiz nazariyesi

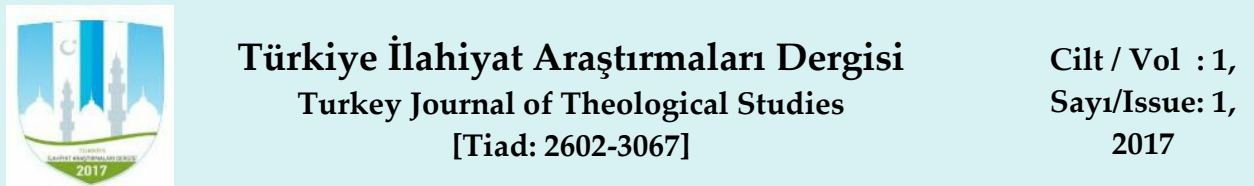


Değer kaybının ödenmesi noktasında dikkat edilmesi gereken bazı hususlar da bulunmaktadır. Bunlar şu şekilde özetlenebilir:

a) Değer kaybı alacaklı taraf açısından genel olarak (örfen) kabul edilebilir bir oranın üstünde olmalı ve bir zarar meydana getirmelidir.

b) Borç, bir satım akdinden doğmuşsa; belirlenen vade, alacaklıya zarar verecek bir süre aşılmış olmalı ve değer kaybı vade farkı olarak fiyata yansıtılmış olmamalıdır. Karz akdinde ise ödemeye ek belli bir miktar veya vadeye karşıllı olarak bir oran önceden belirlenmemelidir.

c) Zimmette sabit olan para borcunun, değer kaybı eklenmiş haliyle yeni bedelle ödenmesi durumunda ödemenin derhal yapılması gerekir.

d) Enflasyon ve değer kaybı, piyasanın tabii seyri içinde normal şartlarda oluşmalı, spekülatif veya devlet kaynaklı ve servet sahiplerine yönelik bir uygulama olmamalıdır.

\section{Kaynakça}

Bakkal, Ali, "İslam Hukukunda Para Faiz Telakkisi Zaviyesinden Enflasyon Farkının Ödenmesi Problemi", Harran Üniversitesi İlahiyat Fakültesi Dergisi, Sayı I, Şanlıurfa, 1995.

Buhârî, Ebû Abdillâh Muhammed b. İsmâill, Sahîhu'l-Buhârî, Dâru Tûki'n-Necât $1422 / 2001$.

Dönmez, İbrahim Kâfi, "Maslahat", Türkiye Diyanet Vakfi İslam Ansiklopedisi (DIA), İstanbul: 2003, c. XXVIII, ss. 79-94.

Gözübenli, Beşir "Kıyemî”, Türkiye Diyanet Vakfı İslam Ansiklopedisi (DİA), İstanbul: 2002, c. XXV, ss. 540-541.

Hacak, Hasan "Mislî”, Türkiye Diyanet Vakfı İslam Ansiklopedisi (DİA), İstanbul: 2005, c. XXX, ss. 187-188.

Heyet, Mecelle, Mecelle-i Ahkam-ı Adliye, Ali Himmet Berki Neşri, İstanbul, Hikmet Yayınları, 1985.

İbn Abidin, Muhammed Emin b. Ömer, Redd'ul-Muhtâr ale'd-Durri'l-Muhtâr, Beyrut, Dâru'l-Fikr, 1412/1992.

İbn Abidin, Muhammed Emin b. Ömer, Tenbih'ur-Rukûd ala Mesâili'n-Nukûd, Mecmuatu'r-Resail, Mektebetü'l-İslamiyye, tsz.

İbn Kudâme el-Makdisî, Ebû Muhammed Muvaffakuddin Abdullah b. Ahmed, el-Mŭgnhî, Mektebetu'l-Kâhire tsz.

İbn Mâce, Ebû Abdillâh Muhammed b. Yezîd el-Kazvînî, Sünen, Dâru'rRisâleti'l-İlmiyye 1430/2009. 
Kâsânî, Alâüddîn Ebû Bekr b. Mes'ûd, Bedâiu's-Sanâi' fî̀ Tertîbi'Şerâi', Dâru'lKutubu'l-İlmiyye 1406/1986.

Nevevî, Ebû Zekeriyya Muhyiddin Yahya b. Şeref, el-Mecmû Şerhu'l-Muhezzeb, Beyrut, Dâru'l-Fikr, tsz.

Remlî, Şemseddin Muhammed b. Ahmed, Nihâyetu'l-Muhtâc ilâ Şerhi'l-Minhâc, Beyrut, Dâru'l-Fikr, 1404/1984.

Serahsi, Şemsu'l-Eimme Muhammed b. Ahmed, el-Mebsut, Beyrut, Dâru'lMarife, 1414/1993.

Zuhayli, Vehbe, Fıkhu'l-İslâmî ve Edilletuhu, Dımeşk, Dâru'l-Fikr, tsz. 